\title{
Risks of pressure injury: application of the Braden Scale in intensive care
}

\author{
Riscos de lesão por pressão: aplicação da Escala de Braden em terapia intensiva
}

Riesgos de lesión por presión: aplicación de la Escala de Braden en terapia intensiva Leila Roberta Cordeiro de Lima Santos ${ }^{1}$, Alexandra Isabel de Amorim Lino ${ }^{2}$

\section{ORCID IDS}

Santos LRCL (iD https://orcid.org/0000-0002-2725-9261

Lino AlA (iD https://orcid.org/0000-0003-0988-2284

\section{HOT TO CITE}

Santos LRCL; Lino AIA. Risks of pressure injury: application of the Braden Scale in intensive care. ESTIMA, Braz. J. Enterostomal Ther., 16: e0818. doi: 10.30886/estima.v16.443.

Monograph "Risk evaluation of pressure injury from the application of the Braden Scale in patients of an Intensive Care Unit of the Distrito Federal" presented to the School of Health Sciences, as a requirement for Specialization in Nursing Residency in Intensive Care, Fundação de Ensino e Pesquisa em Ciências da Saúde, Brasília/DF, Brazil, 2016.

\begin{abstract}
Objectives: To identify, through the application of the Braden Scale, the risk of patients admitted developing pressure injuries (PI) and to verify the nursing care provided to prevent the incidence of these injuries in patients of an Intensive Care Unit (ICU) in the Base Hospital of the Distrito Federal. Method: Descriptive, quantitative and cross-sectional study. The study site was the Neurotrauma ICU of the Base Hospital of the Distrito Federal. Data were collected through the application of the Braden Scale within 72 hours of patient admission. A total of 96 individuals participated in the study. Results: The results showed that from the risk evaluation, the index that had the highest percentage in the subscale was activity, followed by the friction/ shear and mobility subscales. Conclusion: The research showed that all patients hospitalized at the unit presented some risk, whether low, moderate or high, to develop PI.
\end{abstract}

DESCRIPTORS: Tertiary prevention; Nursing care; Risk factors; Stomatherapy

\footnotetext{
1Secretaria de Estado de Saúde do Distrito Federal - Fundação de Ensino e Pesquisa em Ciências da Saúde - Programa de Residência em Enfermagem em Unidade de Terapia Intensiva - Brasília/DF - Brazil.

${ }^{2}$ Hospital de Base do Distrito Federal - Diretoria de Ensino e Pesquisa - Programa de Residência em Enfermagem Cirúrgica Brasília/DF - Brazil.

Correspondence author: Leila Roberta Cordeiro de Lima Santos | Quadra 301, conj. 02, lotes 9 a 17 e 19 a 22, apart. 1401, bloco D, Edifício Via Solare - Samambaia Sul | ZIP Code: 72300-533 - Brasília/DF - Brazil | E-mail: leilarcls@yahoo.com.br

Received: Jan 102017 | Accepted: Dec 142017
} 


\section{RESUMO}

Objetivos: Identificar, por meio da aplicação da Escala de Braden, o risco de os pacientes admitidos desenvolverem lesão por pressão (LP) e verificar o cuidado de enfermagem prestado para prevenção da incidência dessas lesões em pacientes de uma Unidade de Terapia Intensiva (UTI) no Hospital de Base do Distrito Federal. Método: Estudo descritivo, quantitativo e transversal. O local de estudo foi a UTI de Neurotrauma do Hospital de Base do Distrito Federal. A coleta de dados ocorreu por meio da aplicação da Escala de Braden em até 72 horas após a admissão do paciente. No total, 96 indivíduos participaram da pesquisa. Resultados: Os resultados mostraram que a partir da avaliação de risco o índice que teve maior percentual na subescala foi atividade, seguido das subescalas fricção/cisalhamento e mobilidade. Conclusão: A pesquisa demonstrou que todos pacientes internados na unidade apresentaram algum risco, seja ele baixo, moderado ou alto, de desenvolver LP.

DESCRITORES: Prevenção terciária; Cuidados de enfermagem; Fatores de risco; Estomaterapia.

\section{RESUMEN}

Objetivos: Identificar, por medio de la aplicación de la Escala de Braden, el riesgo de los pacientes admitidos que desarrollaron lesión por presión (LP) y verificar el cuidado de enfermería brindado para la prevención de la incidencia de estas lesiones en pacientes de una Unidad de Terapia Intensiva (UTI) en el Hospital de Base del Distrito Federal. Método: Estudio descriptivo, cuantitativo y transversal. El lugar de estudio fue la UTI de Neurotrauma del Hospital de Base del Distrito Federal. La recolecta de datos ocurrió por medio de la aplicación de la Escala de Braden en hasta 72 horas después de la admisión del paciente. En total, 96 individuos participaron de la investigación. Resultados: Los resultados mostraron que a partir de la evaluación de riesgo el índice que tuvo mayor porcentaje en la subescala fue actividad, seguido de las subescalas fricción/cizallamiento y movilidad. Conclusión: La investigación demostró que todos los pacientes internados en la unidad presentaron algún riesgo, ya sea el bajo, moderado o alto, de desarrollar LP.

DESCRIPTORES: Prevención terciaria; Cuidados de enfermería; Factores de riesgo; Estomaterapia..

\section{INTRODUCTION}

The appearance of injuries in hospitalized patients has been a constant concern in health units for a long time. This concern increases when we refer to patients hospitalized in Intensive Care Units (ICU), who, most of the time, are in sedoanalgesia and restricted to the bed, thus favoring the appearance of pressure injuries (PI).

The PI has localized origin, with involvement of skin and soft tissues in areas of bony prominences and/ or medical devices. It may also present with whole or ulcerated skin, due to the combination of intense and/ or prolonged pressure and shear ${ }^{1}$.

The prevention of PI appearance in hospitalized patients is the obligation of all health professionals, therefore, the nursing team has an important role in this function, since care is their main object of work. Thus, the appearance of PI in hospitalized patients can be used as an indicator of the care quality provided by the nursing team, and it is incumbent on it to identify the risk factors for PI development in clients and to plan preventive actions in order to improve the quality of assistance due to them ${ }^{2}$.

Some conditions may interfere with the occurrence of PI, among them the bed restriction, which favors a continuous pressure on a region, malnutrition, dehydration, impaired blood circulation, weight loss and exposure of bony prominences; such factors favor the occurrence of injuries and may exacerbate existing ones with the presence of infections, making treatment more difficult and costly ${ }^{3}$.

The use of an instrument to detect early the possibility of a patient developing PI is essential for the adoption of preventive measures, thus favoring a better outcome of the implemented care. Therefore, it is justified to use the Braden Scale, since it can identify the nutritional state, level of mobility, sensory perception, friction, shear, humidity and physical activity level of the patient, verifying the risk of PI involvement during the period in which he is hospitalized in the unit.

The Braden Scale frequently used in Brazil to risk evaluation of a patient developing PI was published in 1987 and a few years later in 1999 it was validated for Brazil. It presents six subscales, such as sensory perception, moisture, activity, mobility, nutrition and friction and shear. Each subscale is scored from 1 to 4 , except for friction and shear, which are scored from 1 to 3; being the maximum score 23 and the minimum score 6. Patients classified with a score of $<11$ are considered at high risk of developing PI; between 12 
and 14 , moderate risk; between 15 and 16, low risk; and between 17 and 23, without risk ${ }^{4}$.

When applying a scale to evaluate the risk of a patient developing PI, the health professional demonstrates concern and priority in decreasing the appearance of these often avoidable injuries, improving their care ${ }^{5}$.

The friction occurs when two surfaces move together, thus leading to abrasion and often to the appearance of blisters, damage restricted to the epidermis and dermis. The shear is a force that arises mainly due to mobilization and incorrect positioning, leading to a deeper tissue injury. These friction and shear forces occur preferentially in bedridden patients who are maintained with an elevated bedside, at an angle above 30 degrees, causing them to slip in the bed and causing frequent injuries in the sacral region ${ }^{6}$.

In view of the above, this research arose from a necessity to alert health professionals about the risk of patients hospitalized in ICU to develop PI and to encourage the development of actions that contribute to adequate assistance in the prevention of these injuries.

\section{OBJECTIVES}

To identify, through the application of the Braden Scale, the risk of the admitted patients to develop PI and verify the nursing care provided to prevent the incidence of these injuries in patients of an ICU of the Base Hospital of the Distrito Federal (BHDF), in the period comprised between January and March 2016, in addition to identifying and characterizing the profile of individuals admitted to this ICU and to verify and relate the flow of entries in that period.

\section{METHOD}

It is a descriptive, quantitative and prospective study. The study site was the Neurotrauma ICU of the BHDF and the patients were admitted to this ICU from January to March 2016. The average monthly number of patients admitted to this ICU is 37 patients. It is a tertiary-level hospital, linked to the Distrito Federal Health Department, which receives patients for intensive treatment, specifically those who suffered neurological trauma, having a total of 20 beds.

The inclusion criteria were patients older than 18 years and who had personal and clinical data in the electronic medical record from January to March, 2016; patients or relatives who refused to sign the Informed Consent Term and patients under the age of 18 were excluded.

The data were collected through the application of the Braden Scale within 72 hours after admission of the patient and in the records in the electronic handbook. The score relation versus risk is inversely proportional, so the lower the value of the score, the greater the risk of the individual to develop PI. The data collected were cataloged in tables in the program Microsoft Excel ${ }^{\circledR}$ 2007 , in addition to data regarding the profile and risk of PI development in the individual; later, analysis and correlation with the existing literature were performed.

The sample was composed of 112 individuals in this ICU, victims of trauma, but 16 did not attend the inclusion criteria and were excluded, totaling 96 individuals who participated in the study.

The project was approved by the Ethics Committee of the Health Science Teaching and Research Foundation of the Distrito Federal Health Department under the number CAAE 50419715.7.0000.5553 and the requirements of Resolution $n^{\circ} .466 / 2012$ of the National Council of Health/ Ministry of Health were respected.

\section{RESULTS}

Among the 96 individuals evaluated, 74 (77.1\%) were men, followed by $22(22.9 \%)$ women. In relation to the age group, there was a hegemony between the age ranges, $25(26.0 \%)$ individuals in the range of 18 to 31 years and also in the range of 46 to 59 years, 26 (27.1\%), were in the range between 32 and 45 years and $20(20.8 \%)$ were over 60 years, as specified in Table 1.

The age range between 18 and 45 years numbered 51 (53.1\%) individuals, the majority of whom were men, mainly due to the profile of the study unit, since the sector is specialized in the care of patients who have suffered neurological traumas and these types of injuries affect the majority of young men, mainly due to external causes. 
The Table 2 shows the distribution of the Braden Scale scores for the evaluation of patients up to 72 hours after admission to the ICU.

There was an evident predominance of patients classified as having a score of $<11$, with $18(81.8 \%)$ women and 62

Table 1. Distribution by age group, and gender of the examined population between January and March 2016, Distrito Federal.

\begin{tabular}{cccc}
$\begin{array}{c}\text { Age } \\
\text { (years) }\end{array}$ & $\begin{array}{c}\text { Female } \\
\mathbf{n}(\%)\end{array}$ & $\begin{array}{c}\text { Male } \\
\mathbf{n}(\%)\end{array}$ & $\begin{array}{c}\text { Total } \\
\mathbf{n}(\%)\end{array}$ \\
\hline 18 to 31 & $3(3.1 \%)$ & $22(22.9 \%)$ & $25(26.0 \%)$ \\
\hline 32 to 45 & $5(5.2 \%)$ & $21(21.9 \%)$ & $26(27.1 \%)$ \\
46 to 59 & $9(9.4 \%)$ & $16(16.7 \%)$ & $25(26.1 \%)$ \\
\hline > 60 & $5(5.2 \%)$ & $15(15.6 \%)$ & $20(20.8 \%)$ \\
\hline Total & $22(22.9 \%)$ & $74(77.1 \%)$ & $96(100 \%)$ \\
\hline
\end{tabular}

$\mathrm{n}$ = absolute frequency; $\%$ = percentage frequency.

Table 2. Gender score of the Braden Scale of the population studied between January and March 2016, Distrito Federal.

\begin{tabular}{ccc} 
Score & $\begin{array}{c}\text { Female } \\
\mathbf{n}(\%)\end{array}$ & $\begin{array}{c}\text { Male } \\
\mathbf{n}(\%)\end{array}$ \\
\hline$<11$ & $18(81.8 \%)$ & $62(83.8 \%)$ \\
\hline 12 to 14 & $3(13.6 \%)$ & $12(16.2 \%)$ \\
\hline 15 to 16 & $1(4.6 \%)$ & $0(0.0 \%)$ \\
\hline 17 to 23 & $0(0.0 \%)$ & $0(0.0 \%)$ \\
\hline Total & $22(100 \%)$ & $74(100 \%)$ \\
\hline
\end{tabular}

$\mathrm{n}=$ absolute frequency; $\%$ = percentage frequency.
$(83.8 \%)$ men, thus being considered at high risk to develop injuries. In the range of 12 to 14 , three (13.6\%) patients were women and $12(16.2 \%)$ were men. There were no patients classified between scores 17 and 23, thus evidencing that all the hospitalized in this unit had some risk of PI appearance.

Figure 1 shows the risk evaluation of the patients developing PI, with the highest percentage index the activity subscale (bedridden/confined to bed), followed by the friction and shear subscales (problem/ requires moderate to maximum help) and mobility (does not make any movement/completely immobilized).

As to the result on sensorial perception, which refers to the ability to respond significantly to the pressure related to discomfort, 80 (83.3\%) patients were totally limited and 12 (13.5\%) were very limited, corresponding to 92 patients (96.8\%). Regarding moisture, 58 individuals (60.4\%) presented skin that was rarely wet. Regarding the degree of activity, 96 patients (100\%) were totally restricted to the bed, mainly due to the profile of the ICU being Neurotrauma, with the majority of patients in deep sedation or with neurological sequelae. Regarding mobility, 91 patients (94.8\%) were completely immobile, also due mainly to the use of sedative drugs. Very poor nutrition was identified in 52 patients (54.2\%), because many of them were evaluated after a surgical procedure and were therefore on a zero diet. And in relation to friction and shear, 95 patients (99\%) needed maximum to moderate assistance to move.

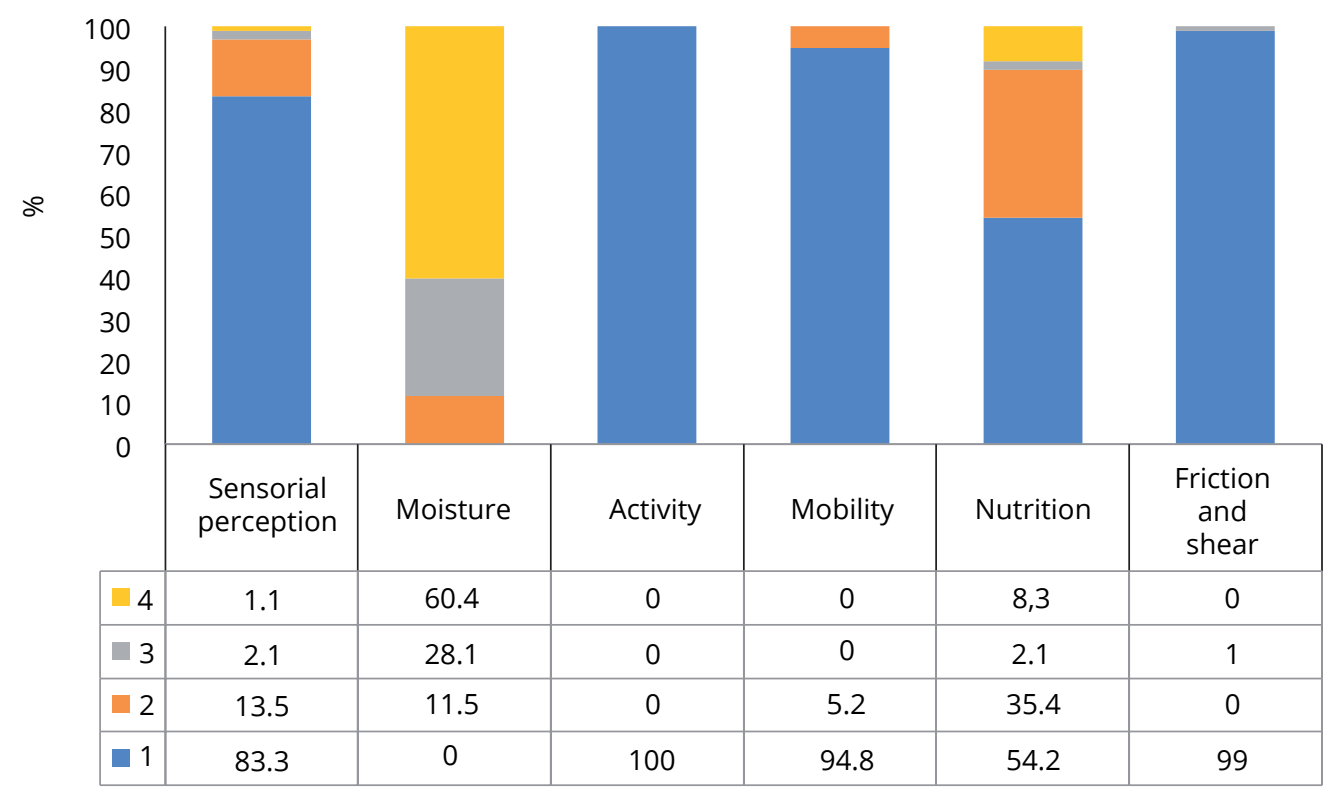

Figure 1. Percentages per subscale of the examined population. 
During the three months of the research, it was possible to observe the performance of the professionals in the unit and it was verified that regarding the positioning of the patient in the bed with head raised to 30 degrees to avoid forces of friction and shear, this was realized; however, the practice of changing the decubitus or repositioning in the bed every 2 hours was not performed respecting the correct periods, which favored the appearance of PI. Several failures in the nursing professionals' performance were justified by the insufficient amount of human resources in this sector, leading professionals to prioritize other actions, such as drug administration and the evaluation of vital signs, among other care.

\section{DISCUSSION}

Between January and March 2016, 4.217 people were hospitalized in the Distrito Federal for external causes, 2.630 were between 15 and 49 years of age, and 2.078 (79.01\%) were men among them ${ }^{7}$, thus corroborating the data found in this study most of which belonged to the male gender.

The risk of developing PI, according to age limits, ranged from 18 to 83 years, with emphasis on individuals below 59 years. This countered other studies that associate aging and its factors, such as poor neurological status, inadequate nutrition, impaired mobility, impaired physical activity and incontinence, favoring the appearance, recurrence and worsening of PI, also leading to prolonged hospitalization ${ }^{8}$. It is possible that this discrepancy is related to the fact that the type of patient screened for this ICU is, mostly, victims of trauma.

Regarding the classification of the score value, it can be seen that the subcategories activity, friction/shear and mobility were the ones that had a lower index, thus characterizing greater dependence of the patients in these questions and requiring more frequent actions of the professionals to compensate for these deficiencies. Some researches in Brazil show that the scores presented in the application of the Braden Scale in the initial evaluation advise nurses to identify the patients who are more likely to develop PI, in order to contribute that the professional to program early strategies to avoid the appearance of these injuries ${ }^{9-11}$.
Among the measures to reduce friction, is the repositioning of the patient without dragging it in the bed; for this purpose, mechanical elevators can be used to aid in the lifting of heavier individuals, in which two professionals have difficulty performing this movement. To prevent shearing, the position that least interferes is that in which the bedside has only a 30 degree elevation; However, due to several clinical factors, it is not always possible to maintain this elevation ${ }^{12}$.

In relation to the subcategories, mobility is the requirement of greater impact on the appearance of PI. Keeping the patient in the same body position for a long time can lead to a gravitational gradient that interferes with the cardiovascular and pulmonary systems, which consequently leads to a decrease in oxygenation and blood supply in the extremities, favoring the appearance of these injuries ${ }^{13}$.

For proper movement and based on recommendations, we have the patient's positioning with the aid of a trapezium or moving sheet, determining a 30-degree lateralization so that there is no direct pressure in the sacral or trochanteric region and scheduling a regular repositioning according to individualized evaluation ${ }^{12}$.

It is known that patients who present alterations in sensorial perception cannot perceive the discomfort generated by the excessive pressure in the tissues caused by the continuous stay in a single position. Thus, even if the ways are used that favor the decompression of these places, nursing care with bed repositioning is essential to prevent the appearance of PI, using adequate support surfaces according to the risk of developing PI, including mattresses such as pneumatic and pyramidal. As the evaluated patients presented many limitations for movement due to the need of neuroprotection, it is necessary to evaluate the use of dynamic surfaces that distribute the load and thus obtain maximum protection.

The moisture to which the skin is exposed may be related to urinary or fecal incontinence, leaving it prone to the appearance of PI secondary to friction and dermatitis associated with incontinence. Its appearance is more predisposed when the urinary and fecal incontinence happen simultaneously, leaving the skin even more fragile, due to the increase of its $\mathrm{pH}$. The importance of using contact barriers, such as appropriate hydrating cream and ointments, absorbent diapers and, in particular, 
the late bladder catheter in order to reduce the skin's exposure to moisture ${ }^{11}$.

As for nutrition, studies show that individuals who present nutritional disorders are more susceptible to the development of PI and become more resistant to treatment, since malnutrition directly interferes in the healing of the injuries and, consequently, the patient becomes more vulnerable to infections, besides prolonging their hospitalization ${ }^{14,15}$. In a study of PI incidence, developed in an ICU in São Paulo, it was observed that malnutrition directly contributes to the risk of PI formation due to the decrease in pressure tolerance. Such deficient ICU nutrition is usually associated with the patient's disease status, surgical procedures and hypermetabolism, among other factors ${ }^{9}, 16$, ${ }^{17}$. In this study, we observed that the surgical procedure was common to several patients and the necessary fast for this influenced the nutritional aspect of the risk evaluation for PI development, since several patients were evaluated in the return of the procedure, still fast.

The friction and shear were important variables in the study, due to the large number of patients who needed moderate to maximum assistance to move.

\section{CONCLUSION}

The use of the Braden Scale to evaluate the risk of developing PI showed that all patients hospitalized at the unit had some risk, whether low, moderate or high. These data show that the instrument can be used by nurses to assist in the planning of preventive actions and aimed at controlling the appearance of injuries in patients admitted to the ICU.
It was observed, within the particularity of the place studied, that the majority of the patients were male, was in the age group of 18 to 45 years and presented a scoring score lower than 11, which expresses a high risk for PI development. Among the variables with less score, we have sensory perception, activity, mobility and friction and shear. Based on this, measures are needed for injury prevention and risk elimination; for this, it is necessary that the support surface be dynamic, that there are regular repositions with lateralization of 30 degrees, if using supports to maintain the positioning, and that a bedside with 30 degrees elevation, according to clinical state, is maintained, to diminish the friction and shear forces.

The study presented a limitation in the evaluation of patients' nutritional status, since most of them were in the immediate postoperative period, favoring an impaired evaluation, which reinforces the need to apply the Braden scale and its constant reapplication.

It is suggested that the application of the Braden Scale be routinely implanted in this ICU, together with periodic training of the team, to assist in the care provided and to provide subsidies for the implementation of strategies aimed at reducing PI in these units.

\section{AUTHOR'S CONTRIBUTION}

Conceptualization, Santos LRCL and Lino AIA; Methodology, Santos LRCL and Lino AIA; Research, Santos LRCL; Writing - First version, Santos LRCL and Lino AIA; Writing - Review \& Editing, Santos LRCL and Lino AIA; Acquisition of Financing, Santos LRCL and Lino AIA; Resources, Santos LRCL and Lino AIA; Supervision, Santos LRCL and Lino AIA.

\section{REFERENCES}

1. Associação Brasileira de Estomaterapia, Associação Brasileira de Enfermagem em Dermatologia, Caliri MHL, Santos VLCG, Mandelbaum MHS, Costa IG. Classificação das lesões por pressão - consenso NPUAP 2016 - Adaptada culturalmente para o Brasil [Internet]. [cited in 21 apr 2017]. Available at: http://www.sobest.org.br/textod/35

2. Sousa CA, Santos I, Silva LD. Aplicando recomendações da Escala de Braden e prevenindo úlceras por pressão: evidências do cuidar em enfermagem. Rev
Bras Enferm. 2006;59(3):279-84. doi: 10.1590/s003471672006000300006.

3. Freitas JPC, Alberti LR. Aplicação da Escala de Braden em domicílio: incidência e fatores associados a úlcera por pressão. Acta Paul Enferm. 2013;26(6):515-21. doi: 10.1590/ s0103-21002013000600002.

4. Araújo CRD, Lucena STM, Santos IBC, Soares MJGO. A enfermagem e a utilização da Escala de Braden em úlcera por pressão. Rev Enferm UERJ. 2010;18(3):359-64. 
5. Smeltzer SC, Bare BG. Brunner\&Suddarth: Tratado de enfermagem médico-cirúrgica. 10a ed. vol. 1. Rio de Janeiro: Guanabara Koogan; 2005.

6. Marchiore AC, Alves AC, Leite EMP, Moreira LR, Oliveira MRJS, Sant'Ana VM, et al. Utilização das Escalas de Avaliação de Risco para Úlcera por Pressão em Unidades de Terapia Intensiva de São Paulo. Rev Estima. 2015;13(2):53-61. doi: 10.5327/z1806-3144201500020004.

7. Brasil, Ministério da Saúde, DATASUS. Informações de saúde epidemiológicas e morbidade: causas externas por internação [Internet]. 2016 [cited in 16 oct 2016]. Available at: http://tabnet.datasus.gov.br

8. Souza DMST, Santos VLCG. Úlceras por pressão e envelhecimento. Rev Estima. 2006;4(1):36-44.

9. Paranhos WY, Santos VLCG. Avaliação do risco para úlcera de pressão por meio da Escala de Braden na língua portuguesa. Rev Esc Enferm USP. 1999;33(N. Esp):191-204.

10. Rogenski NMB, Santos VLCG. Estudo sobre a incidência de úlceras por pressão em um hospital universitário. Rev Latino-Am Enferm. 2005;13(4):474-80. doi: 10.1590/s010411692005000400003.

11. Fernandes LM, Caliri MHL. Uso da Escala de Braden e de Glasgow para identificação do risco para úlceras de pressão em pacientes internados em centro de terapia intensiva.
Rev Latino-Am Enferm. 2008;16(6):973-8. doi: 10.1590/ S0104-11692008000600006.

12. Caliri MHL Ações recomendadas para diminuição do risco para úlcera por pressão em pacientes restritos ao leito ou cadeira. In: Blanes L, Ferreira LM. Prevenção e tratamento de úlcera por pressão. São Paulo: Atheneu; 2014.

13. Maklebust J, Sieggreen M. Pressure ulcer: guidelines for prevention and nursing management. Pennsylvania: Springhouse Corporation; 2000.

14. Wound, Ostomy and Continence Nurses Society (WOCN). Guideline for prevention and management of pressure ulcers. WOCN Clinical Practice Guidelines Series. Glenview: WOCN; 2003.

15. Aguiar JM, Paiva SS. Escala de Braden: avaliação dos fatores de risco para úlcera de pressão em pacientes internados em uma Unidade de Terapia Intensiva. Rev Hosp Univ UFMA. 2003;1(1/2): 39-44.

16. Vollman KM. The right position at the right time: mobility makes a difference. Intensive Crit Care Nurs. 2004;20(4):17982. doi: 10.1016/j.iccn.2004.06.002.

17. Braden B, Bergstrom N. A conceptual schema for the study of the etiology of pressure sores. Rehabil Nurs. 1987;12(1):812. doi: 10.1002/j.2048-7940.1987.tb00541.x. 